\title{
Why Mozart compositions during pregnancy should be exposed in the night. Study on apoptotic index of Rattus norvegicus offsprings' brain neurons
}

\author{
Eka Nasrur Maulana', Hermanto Tri Joewono', Widjiati², Windhu Purnomo ${ }^{3}$ \\ 'Department of Obstetrics and Gynecology, School of Medicine, University of Airlangga, dr. Soetomo General \\ Hospital, ${ }^{2}$ Department of Embriology, Faculty of Veterinary Medicine, University of Airlangga, ${ }^{3}$ Department of \\ Biostatistics and Demography, Faculty of Public Health, University of Airlangga, Surabaya, Indonesia.
}

\section{ABSTRAK}

Tujuan: membuktikan bahwa saat paparan musik Mozart yang optimal pada Rattus norvegicus bunting adalah malam hari/ gelap dengan mengukur perbedaan pengaruhnya terhadap indeks apoptotis sel neuron otak Rattus norvegicus baru lahir.

Bahan dan Metode: Studi ini menggunakan desain penelitian analitik eksperimental randomized post test only control group design menggunakan hewan coba Rattus norvegicus sebagai subyek pemberian stimulus musik Mozart. Subyek dibagi dalam tiga kelompok secara acak, yakni kelompok kontrol, perlakuan 1 (1 jam komposisi Mozart saat gelap) dan perlakuan 2 (1 jam komposisi Mozart saat terang), masing-masing 8 induk Rattus norvegicus. Setelah melahirkan, dipilih 2 anak Rattus norvegicus betina paling berat, total 15 anak masing-masing kelompok, lalu dikorbankan dengan dekapitasi lalu otaknya dipersiapkan dan diwarnai meng-gunakan metode TUNEL assay kemudian dilakukan pengukuran indeks apoptosis sel neuron anak Rattus norvegicus pada akhir penelitian dengan pembesaran mikroskop 1000x. Studi ini dilakukan di Fakultas Kedokteran Hewan Universitas Airlangga setelah dilakukan uji kelayakan etik.

Hasil: Tidak terdapat keguguran, cacat bawaan, kelahiran preterm dan kematian bayi Rattus norvegicus baru lahir pada semua kelompok. Indeks apoptosis sel neuron kelompok kontrol adalah $55,98 \pm 4,12$, kelompok satu $24,87 \pm 3,45$ dan kelompok dua 23,82 \pm 3,89 . Tidak didapatkan beda indeks apoptosis yang bermakna antara kelompok perlakuan 1 dan $2(\mathrm{p}=0,836)$, tetapi didapatkan perbedaan bermakna antara kelompok kontrol dengan perlakuan 1 $(\mathrm{p}=0,002)$ dan antara kelompok kontrol dan kelompok perlakuan 2 $(\mathrm{p}=0,009)$. Didapatkan pula pada kelompok gelap: mempunyai rata-rata indeks apoptosis terendah, indeks apoptosis terendah, 9 dari 15 subyek mempunyai indeks apoptosis terendah, berat kepala tertinggi, 4 dari 15 subyek mempunyai berat tertinggi,

Kesimpulan: Tidak didapatkan perbedaan indeks apoptosis yang bermakna antara pemberian musik Mozart saat terang atau gelap pada sel neuron otak anak Rattus norvegicus meskipun rataratanya lebih rendah terutama bila nilai ekstrim dikeluarkan. Namun pada kelompok gelap: mempunyai rata-rata indeks apoptosis terendah, terdapat berat kepala tertinggi, proporsi subyek mempunyai berat tertinggi, indeks apoptosis terendah, dan proporsi terbesar subyek dengan indeks apoptosis terendah. (MOG 2017;25:97-102)

Kata kunci: Paparan Mozart dalam kehamilan, terang, gelap, indeks apoptosis sel neuron

Correspondence: Eka NM, Hermanto TJ - Department of Obstetrics and Gynecology, School of Medicine, University of Airlangga, Dr Soetomo General Hospital, Prof. Dr. Moestopo 6-8, Surabaya 60286, Indonesia. hermanto.tri@fk.unair.ac.id

\begin{abstract}
Objectives: To analyze the optimal time to expose Mozart compositions(in the night/ dark) by measuring brain neural apoptotic index of Rattus norvegicus offsprings

Materials and Methods: This study used experimental randomized post test only control group design in pregnant Rattus norvegicus. Subjects were divided into three groups at random, ie control group, 1 (1 hour Mozart exposure in dark) and 2 (1 hour Mozart in light), each comprised 8 females. After delivery, 2 heaviest Rattus norvegicus offsprings were chosen, totally 15 neonates in each group, then they were sacrificed with decapitation and the brain was prepared and stained using TUNEL assay method and the index of neurons cell apoptosis was calculated using microscope in 1000x magnification. This study was conducted at the Faculty of Veterinary Medicine, University of Airlangga, after conducting ethical feasibility test.

Results: There were no miscarriages, congenital malformation, preterm birth and deaths in all groups. The control group's neural apoptosis index was $55.98 \pm 4.12$, group one $24.87 \pm 3.45$ and group two $23.82 \pm 3.89$. Based on statistical test result, there was no significant difference of apoptosis index between treatment group 1 and treatment group 2 , with $p$ value 0,836 but significant difference was found between control group and treatment group $1(\mathrm{p}=0.002)$ and between control group and treatment group 2 $(\mathrm{p}=0.009)$. In dark group we found the lower average of apoptotic index, the lowest apoptotic index, 9 of 15 had the lowest, the heaviest head weight and 4 of 15 subjects had the heaviest head weight

Conclusion: There was no significant difference between the provision of Mozart music in dark and light on brain neuron of Rattus norvegicus offsprings although lower average in the dark group especially if the extreme value exluded. In the dark group: we found the lower average of apoptotic index, the lowest apoptotic index, biggest proportion of the lowest index, the heaviest head and biggest proportion of heaviest head. (MOG 2017;25:97-102)
\end{abstract}

Keywords: Mozart compositions, pregnancy, Rattus norvegicus offsprings, neuronal apoptotic index, light and dark

\section{INTRODUCTION}

Having a smart child is the hope of every parent, and to achieve that expectation, parents will provide nutritious food. According to Gardner, intelligences are defined as the biopsychosocial potential for processing information that can be activated on a cultural back-ground to solve problems or create products that are beneficial to a cul- 
ture. We use premise that intelligences depend on the number of neurons, glia, dendrites/synapses and the ratio of glia per neuron. The way to increase the number of neurons, glia and sinaptogenesis is environment enrichment by providing combination nutrition including DHA and stimulation. The simplest stimula-tion is by sound. ${ }^{1}$ Combination of sequence of harmonic tone is called music.

Human central nervous system develops rapidly during pregnancy. In addition to proliferation, migration, differentiation, myelination and synaptogenesis neural cells also have apoptosis. The development of human brain occurs most rapidly since the beginning of pregnancy until the age of 2 years after the baby was born. In the third tri-mester of pregnancy, brain growth reaches 5-6 times heavier than that in early pregnancy. The number of fetal brain neuron cells does not increase after about six months of gestation. ${ }^{2,3}$ After six months of gestation, neuron function improves, neuron sheath develops, known as myelinization, and neuron cell apoptosis takes place. If the apoptotic process is inhibited, the number of surviving neurons increase, so that the number of neurons become higher at the time of the birth. Thus, the brain capacity is expected to be improved further. ${ }^{3.4}$

Rees states that the occurrence of apoptotic cells depends on the number of synapses. The higher the number of dendritic sites, the more synapses are formed, so the number of cells undergoing apoptosis will de-crease. Rees also said that environmental influences also determine the number of surviving neuron cells. The more stimulation of the environment, the more synapses are formed, and the greater the number of surviving neurons and the less apoptosis that occurs. Pregnancy is the most appropriate time to prepare for brain potential and it is the most valuable opportunity for parents. ${ }^{4}$
Previous studies of prenatal stimulation using Mozart's music have found elevated levels of BDNF (Brainderived Neurotrophic Factor) and decreased apoptotic indices of brain neuron cells, but there is no fixed procedure that sets the optimal time to reduce apoptotic index to the lowest level. The objective of this study was to determine the optimal exposure time of Mozart music between 1 hour of exposure in light and dark since the day 10 of Rattus norvegicus pregnancy on the apoptotic index of brain neurons of Rattus norvegicus neonates.

\section{MATERIALS AND METHODS}

This study was conducted at Experimental Animal Cage, Pathology Laboratory, Faculty of Veterinary Medicine, University of Airlangga, Surabaya, from April to July 2014 with experimental analytical study using randomized post-test only control group design, involving Rattus norvegicus as models receiving Mozart music stimulus. The subjects were divided into three groups randomly, each of 8 pregnant Rattus norvegicus with duration of exposure to Mozart compositions for 1 hour in light, dark and without exposure.

We performed superovulation with 10 IU PMSG injection, followed by $10 \mathrm{IU}$ hCG injection after 48 hours, then the rats were monomated. After day 10 of pregnancy, 14 Mozart music compositions were exposed at night with the same volume. After childbirth, two heaviest Rattus norvegicus neonates were selected, totally 15 neonates from each group, then sacrificed by decapitation. The brain was prepared and stained using the TUNEL assay method, then the measurement of brain neural apoptotic index of Rattus norvegicus offsprings were performed at the end of the study with in $1000 \mathrm{x}$ microscopic enlargement. TUNEL assay method was used to stain the neural apoptotic cells.

Table 1. Characteristics of Rattus norvegicus based on gestational age

\begin{tabular}{ccccccccc}
\hline & \multicolumn{9}{c}{ Groups } & \multicolumn{2}{c}{ Total } & \\
\cline { 2 - 7 } $\begin{array}{c}\text { Pregnancy } \\
\text { age }\end{array}$ & \multicolumn{2}{c}{ Control } & \multicolumn{2}{c}{$\begin{array}{c}\text { Treatment } \\
1 \text { hour dark }\end{array}$} & $\begin{array}{c}\text { Treatment } \\
1 \text { hour light }\end{array}$ & \multirow{2}{*}{$\mathrm{F}$} & $\%$ \\
\cline { 2 - 7 } & $\mathrm{f}$ & $\%$ & $\mathrm{f}$ & $\%$ & $\mathrm{f}$ & $\%$ & & \\
\hline 19 days & 6 & 40 & 4 & 26.67 & 8 & 53.33 & 18 & 40 \\
20 days & 5 & 33.33 & 8 & 53.33 & 7 & 46.67 & 20 & 44.44 \\
21 days & 4 & 26.67 & 3 & 20 & 0 & 0 & 7 & 15.56 \\
\hline Total & 15 & 100 & 15 & 100 & 15 & 100 & 45 & 100 \\
\hline
\end{tabular}


Table 2. Characteristics of Rattus norvegicus offsprings based on body weight

\begin{tabular}{|c|c|c|c|c|c|c|c|c|}
\hline \multirow{3}{*}{$\begin{array}{l}\text { Body } \\
\text { Weight } \\
\text { (gram) }\end{array}$} & \multicolumn{6}{|c|}{ Groups } & \multicolumn{2}{|c|}{ Total } \\
\hline & \multicolumn{2}{|c|}{ Control } & \multicolumn{2}{|c|}{$\begin{array}{c}\text { Treatment } \\
1 \text { hour dark }\end{array}$} & \multicolumn{2}{|c|}{$\begin{array}{c}\text { Treatment } \\
1 \text { hour light }\end{array}$} & \multirow[t]{2}{*}{$\mathrm{F}$} & \multirow[t]{2}{*}{$\%$} \\
\hline & $\mathrm{F}$ & $\%$ & $\mathrm{~F}$ & $\%$ & $\mathrm{~F}$ & $\%$ & & \\
\hline $3.00-3.49$ & - & - & - & - & - & - & - & - \\
\hline $3.51-3.99$ & - & - & - & - & 5 & 33.33 & 5 & 11.1 \\
\hline $4.00-4.49$ & 12 & 80 & 13 & 86.67 & 10 & 66.67 & 35 & 77.8 \\
\hline $4.50-4.99$ & 3 & 20 & 2 & 13.33 & - & - & 5 & 11.1 \\
\hline Total & 15 & 100 & 15 & 100 & 15 & 100 & 45 & 100 \\
\hline
\end{tabular}

Table 3. Characteristics of Rattus norvegicus offsprings based on head weight

\begin{tabular}{ccccccccc}
\hline & \multicolumn{9}{c}{ Groups } & \multicolumn{3}{c}{ Total } \\
\cline { 2 - 9 } $\begin{array}{c}\text { Head Weight } \\
\text { (gram) }\end{array}$ & Control & \multicolumn{2}{c}{$\begin{array}{c}\text { Treatment } \\
\text { 1 hour dark }\end{array}$} & \multicolumn{2}{c}{$\begin{array}{c}\text { Treatment } \\
1 \text { hour light }\end{array}$} & F & $\%$ \\
\cline { 2 - 9 } & F & $\%$ & F & $\%$ & F & $\%$ & & \\
\hline $1.00-1.09$ & - & - & 1 & 6.67 & - & - & 1 & 2.22 \\
$1.10-1.19$ & 3 & 20 & 2 & 13.33 & - & - & 5 & 11.11 \\
$1.20-1.29$ & 9 & 60 & 3 & 20 & - & - & 12 & 26.67 \\
$1.30-1.39$ & 3 & 20 & 3 & 20 & 6 & 40 & 12 & 26.67 \\
$1.40-1.49$ & - & - & 2 & 13.33 & 9 & 60 & 11 & 24.44 \\
$1.50-1.59$ & - & - & 3 & 20 & - & - & 3 & 6.67 \\
$1.60-1.69$ & - & - & 1 & 6.67 & - & - & 1 & 2.22 \\
$1.70-1.79$ & - & - & - & - & - & - & - & - \\
\hline Total & 15 & 100 & 15 & 100 & 15 & 100 & 45 & 100 \\
\hline
\end{tabular}

Table 4. Characteristics of Rattus norvegicus offsprings based on proportion of apoptotic index

\begin{tabular}{|c|c|c|c|c|c|c|c|c|}
\hline \multirow{3}{*}{$\begin{array}{l}\text { Apoptotic } \\
\text { Index }\end{array}$} & \multicolumn{6}{|c|}{ Groups } & \multicolumn{2}{|c|}{ Total } \\
\hline & \multicolumn{2}{|c|}{ Control } & \multicolumn{2}{|c|}{$\begin{array}{l}\text { Treatment } \\
1 \text { hour dark }\end{array}$} & \multicolumn{2}{|c|}{$\begin{array}{c}\text { Treatment } \\
1 \text { hour light }\end{array}$} & \multirow[t]{2}{*}{$\mathrm{F}$} & \multirow[t]{2}{*}{$\%$} \\
\hline & $\mathrm{F}$ & $\%$ & $\mathrm{~F}$ & $\%$ & $\mathrm{~F}$ & $\%$ & & \\
\hline $10-19$ & - & - & 11 & 73.33 & 3 & 20 & 14 & 31.11 \\
\hline $20-29$ & - & - & - & - & 7 & 46.67 & 7 & 15.55 \\
\hline $30-39$ & 2 & 13.33 & 1 & 6.67 & 3 & 20 & 5 & 11.11 \\
\hline $40-49$ & 6 & 40 & - & - & 1 & 6.67 & 7 & 15.55 \\
\hline $50-59$ & 7 & 46.67 & 2 & 13.33 & - & - & 9 & 20 \\
\hline $60-69$ & - & - & - & - & - & - & - & - \\
\hline $70-79$ & - & - & - & - & - & - & - & - \\
\hline $80-89$ & - & - & 1 & 6.67 & 1 & 6.67 & 2 & 4.44 \\
\hline $90-99$ & - & - & - & - & - & - & - & - \\
\hline Total & 15 & 100 & 15 & 100 & 15 & 100 & 45 & 100 \\
\hline
\end{tabular}

Table 5. Test of Rattus norvegicus based on apoptotic index

\begin{tabular}{ccccc}
\hline & \multicolumn{3}{c}{ Groups } & P values \\
\cline { 2 - 4 } Variables & $\begin{array}{c}\text { Control } \\
(\mathrm{x} \pm \mathrm{sd})\end{array}$ & $\begin{array}{c}\text { Treatment } 1 \\
(\mathrm{x} \pm \mathrm{sd})\end{array}$ & $\begin{array}{c}\text { Treatment } 2 \\
(\mathrm{x} \pm \mathrm{sd})\end{array}$ & \\
\hline $\begin{array}{c}\text { Apoptotic } \\
\text { Index }\end{array}$ & $55.98 \pm 4.12$. & $24.87 \pm 3.45$ & $23.82 \pm 3.89$ & $\mathrm{p}=0.836$ \\
\hline
\end{tabular}

significant difference was found between control group and treatment group 1 $(\mathrm{p}=0.002)$ and between control group and treatment group $2(\mathrm{p}=0.009)$ 


\section{RESULTS AND DISCUSSION}

All Rattus norvegicus mothers had a term pregnancy (between 19-21 days). In Table 1, pregnancy age was the highest in the control group at 19 days, dark treatment group at 20 days, and light treatment group at 19 days. The lowest pregnancy age (19 days) was mostly found in 1 hour light group and the highest ( 21 days) in control group.

Characteristics of Rattus norvegicus offsprings based on body weight is shown in Table 3. It appears that biggest head weights were in dark group, ie between 1.20 and 1.29 grams of $9(60 \%)$ rats and in 1 hour light group, ie between 1.40-1.49 gram of $9(60 \%)$ rats. The lowest head weight was found in 1 hour light treatment group, which ranged from 1.00-1.09 grams in 1 (6.67\%) rat and the highest body weight was also found in 1 hour dark treatment group, which ranged from 1.60 to 1.69 in 1 $(6.67 \%)$ rats. In dark group we found the the heaviest head weight and 4 of 15 subjects had the heaviest head weight

Characteristics of Rattus norvegicus offsprings: In dark group we found the lower average of apoptotic index, the lowest apoptotic index, and 9 of 15 had the lowest index. Before comparing neural apoptotic index between each group, Shapiro-Wilk normality test was performed because the number of each group was below 50 sam-ples to determine the calculation method, to use para-metric or non parametric test. Normality test results indicated that all were not normally distributed, except the head weight, so then it was followed by Kruskal Wallis test. The significance value of $\mathrm{p} 0.05$ (5\%) was used in this study, so if the $\mathrm{p}$ value was less than 0.05 then the results were regarded as significant. If the $\mathrm{p}$ value was more than 0.05 , the result was not significant.

In Table 5, it appears that body weight and gestational age do not affect apoptotic index, so the body weight and gestational age are not confounding variables. Table 5 shows that head weight variables also influence the apoptotic index. Since it affected the apoptotic index, head weight should be controlled as a confounding variable with the Ancova test (Table 6).

Table 6. Ancova test on neural apoptosis index with dependent variable

\begin{tabular}{cc}
\hline Variables & P values \\
\hline Corrected model & 0.000 \\
Head weight & 0.005 \\
Groups & 0.000 \\
\hline
\end{tabular}

Table 7. Multiple comparison test between control group, treatment group 1 and treatment group 2

\begin{tabular}{clc}
\hline Groups & \multicolumn{1}{c}{ Groups } & p values \\
\hline Control & 1 h dark & 0.002 \\
& 1 h light & 0.009 \\
1 h dark & Control & 0.002 \\
& 1 h light & 0.836 \\
1 h light & Control & 0.009 \\
& 1 h dark & 0.836 \\
\hline
\end{tabular}

The apoptotic index was calculated between control group, treatment group 1 at dark, and the treatment group 2 at light. Table 7 shows that there is no statistically significant difference $(\mathrm{p}=0.836)$ in the apoptotic index among treatment groups 1 exposed to Mozart music for 1 hour in the dark with treatment group 2 exposed to Mozart music for 1 in light. Significant differences were obtained between control group and treatment groups $1(\mathrm{p}=0.002)$ and group $2(\mathrm{p}=0.009)$.

This study was conducted to determine optimal exposure time of Mozart music for 1 hour between in light and in the dark. In this study it was hypothesized that apoptosis index in the dark will be lower than that in light. In Table 5 all variables such as body weight, head weight and gestational age were normally distribu-ted, then the test was continued with a parametric test using Anova test. The results showed that it was only head weight $(p=0.003)$ that was significant that affected the apoptotic index. It can be said that the variable head weight had a linear relationship with the apoptotic index. Furthermore, Ancova test was performed to determine the effect of control and treatment groups on the apoptotic index. This test was performed to remove head weight from the model. The results showed that significance levels in control group and treatment groups on apoptotic index was 0.000 ( $\mathrm{p}<0.05)$. This shows that without head weight, at $95 \%$ confidence level, there was influence of control and treatment groups of apoptotic index. In dark group we found the lower average of apoptotic index, the lowest apoptotic index, and 9 of 15 had the lowest index

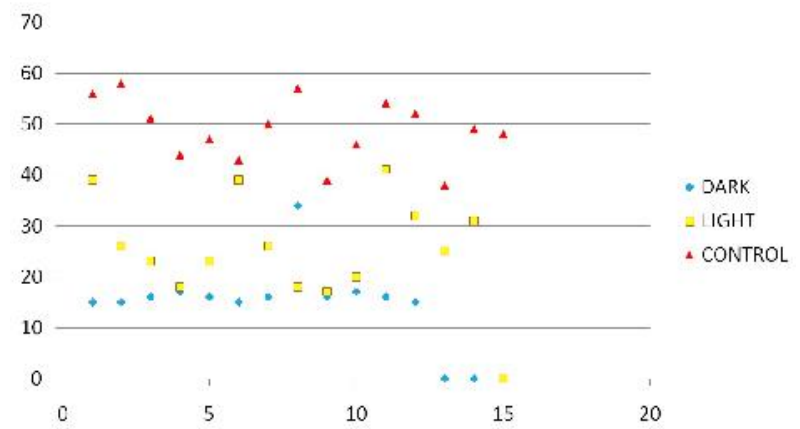

Figure 1. Scatter diagram of apoptotic index in 3 groups 
This study used control - meaning without exposure to Mozart compositions exposure. Based on statistical test, significant differences were obtained between apoptotic index in control group and treatment groups 1 hour in dark and light. Comparison between control group and 1 hour group in dark yielded a p value of 0.002 ( $\mathrm{p}<0.05)$ while control group compared to 1 hour group in light group yielded a $\mathrm{p}$ value of $0.009(\mathrm{p}<0.05)$.

Bures et al. states that the brain that grows in a stimulusrich environment has a thicker cortex, larger cell nuclei and more glial cells. Brain neuron cells that grow in a stimulus-rich environment have more dendritic sites to allow for more synapses. ${ }^{5}$ Rees also states that the number of cells undergoing apoptosis depends on the synapse. The more the synapses, the less apoptosis that occurs. The richer the neuron cells with dendritic sites, the more synapses are formed, so the number of cells undergoing apoptosis will also decrease. The brain that grows in a stimulus-rich environment will experience less apoptosis. Thus, the capacity of the brain will be increased.

Many studies have been done regarding the effect of musical stimulation during pregnancy on the apoptotic index. However, the mechanism of inhibition of apoptosis through this stimulation pathway is still not understood with certainty. The mechanism is very likely to pass through neurotrophic factors known as neurotropin such as Nerve Growth Factor (NGF), Brain-Derived Neurotropic Factor (BDNF) and neurotropin (NT) 3/4/5. BDNF is a growth factor that plays a role in cell proliferation and differentiation and maybe on synaptogenesis.

Music stimulation will stimulate the production of growth factors, including BDNF, CREB (affecting learning and memory factors) as well as synapsin 1 (synaptic protein growth). ${ }^{6,7}$ The target cells produce neurotropin and neuron cells will compete to obtain it as a support for their survival. When neuron cells do not get neurotropin then the cell will die and suffer from apoptosis. Target cells have a certain capacity in producing neurotropin. ${ }^{4,8,9}$

If the target cell's ability to produce neurotropin is increased, the number of cells undergoing apoptosis will also be reduced. However, the mechanism, in which a stimulus will increase the ability of the target cell, in this case another neuron cell, to secrete neurotropin, remains unclear. ${ }^{4}$ Rauscher and Hong Hua Li, in a study conducted on rats exposed to Mozart's music stimulation compared to rats exposed to noisy stimuli, found that rats given Mozart's music stimulus were smarter than rats given a noise stimulus. After the rats' brain was examined, increased expression of BDNF, CREB, and synapsin I was found in rats stimulated by Mozart's compositions compared with control rats. ${ }^{10}$ Mean apoptotic index between treatment group 1 expos-ed to Mozart music for 1 hour in dark (24.875 \pm SE 3.45) and treatment group 2 with 1 hour Mozart music exposure in light (23.825 \pm SE 3.89) was relatively similar. The statistical test obtained $p$ value 0.836 ( $p>0,05)$, indicating no significant difference. If the extreme value exluded, the difference will be more distinct. This does not support our hypothesis that the index of brain cell apoptosis of Rattus norvegicus offsprings exposed to Mozart compositions after pregnancy day 10 for 1 hour in the dark is lower than that form 1 hour in the light.

Almost all living things have a circadian rhythm. In adults circadian rhythms are controlled by biological clocks in the suprachiasmatic nucleus (SCN). SCN affects the heart rate pattern through the sympathetic nervous system. It is unclear whether the fetal SCN can play the same role as adults. However, evidence suggests a large number of glucocorticoid receptors exist in the fetal SCN, indicating that the fetal brain may play a role in the circadian rhythm of the fetus. ${ }^{11}$

Controllers of daily cycle of fetal movement, fetal breathing motion and fetal heart rate patterns are not entirely clear. ${ }^{12}$ The cause of more fetal motion at night is the decrease in blood glucose levels. The cause of the difference in the duration of fetal breathing motion is probably maternal melatonin and adrenal corticoid. ${ }^{13}$ Fetal heart rate patterns are affected by maternal cardiovascular and endocrine. ${ }^{12,13}$ However, control of the circadian rhythm of the fetus is not yet clear.

Whereas, in animals circadian rhythms turned out to be regulated by the hormone melatonin produced by the pineal gland. Melatonin is secreted after it is synthesized in the pineal gland. The mechanism of regulating the hormone melatonin is controlled by the suprachiasmatic nucleus (SCN) which sends the signal through the sympathetic nerves. In Rattus norvegicus, melatonin receptors are present in the suprachiasmatic nucleus, paraventicular nucleus and pituitary. ${ }^{14}$

In our study, the absence of apoptotic index differences between the exposure of Mozart's music for 1 hour in dark music and 1 hour in light was probably due to circadian rhythms of the Rattus norvegicus. Compared with previous study by Hermanto TJ team on our study tree - the result are not in line. We understand that because we realize that the brain is the most complicated entity in the universe and the study on music is still emerging. 


\section{CONCLUSION}

There was no significant difference in the apoptotic index of brain cell neurons of Rattus norvegicus offsprings between those exposed to Mozart's compositions for 1 hour in light and those exposed to 1 hour in dark. This is expected to improve adherence and facilitate pregnant women to provide fetal stimulation with Mozart music during pregnancy, which may result in the output of infants with relatively higher number of brain cells.

\section{REFERENCES}

1. Hermanto TJ. Smart babies through prenatal university: Mission impossible? Majalah Obstetri dan Ginekologi Indonesia. 2004;28(1):14.

2. Hermanto TJ. Bersujud Dalam Rahim 2: Mencerdaskan Janin Sejak Dalam Rahim Dengan Kombinasi Stimulasi 11-14 Musik Karya Mozart dan Nutrisi. Surabaya: Global Persada Pers; 2012.

3. Bear MF, Connor BW, Paradiso MA, 1996. Neuron and Glia. In: Neuroscience: Exploring the Brain. Williams and Wilkins; 2012. p. 22-152.

4. Volpe and Joseph J. Neurology of the newborn, 4th edition. Philadelphia, USA: WB Sauders; 2001. p. 45-99.

5. Rees S and Walker D, 2001. Nervous and neuromuscular systems. In: Harding R and Bocking AD. Fetal growth and development, $1^{\text {st }}$ edition. Cambridge, United Kingdom: Cambridge University Press; p. 154-5.

6. Bures J, Buresova O, Krivanek J. Brain and behavior: Paradigms for research in neural mechanism. Chichester, United Kingdom: John Wiley \& Sons; 2008.
7. Delamasure S, Mehlen P, Ichim G. 2012. Neurotrophins and cell death. Exp Cell Res. 2012;318(11): 1221-8. doi:10.1016/j.yexcr.2012. 03.006. Epub 2012 Mar 18

8. Stadelmann C, Kerschensteiner M, Misgeld T, et al.. BDNF and gp145trkB in multiple sclerosis brain lesions: neuroprotective interactions between immune and neuronal cells? Brain. 2002;125(Pt 1):75-8.

9. Thomaidou D, Mione MC, Cavanagh JFR, Parnavelas JG. Apoptosis and its relation to the cell cycle in the developing cerebral cortex. J Neurosci. 1997;17(3):1075-95

10. Lodish H, Berk A, Matsudaira, et al. 2004. Cell birth, lineage and death. In: Molecular cell biology. New York, USA: WH Freeman and Company; 2004, p. 571-610.

11. Singer E. Molecular basis for mozart effect revealed. New Scientist. 2004.

12. Lunshof S, Boer K, Wolf H, et al. Fetal and maternal diurnal rhytms during the third trimester of normal pregnancy: Outcomes of computerized analysis of continuous twenty-four-hour fetal heart rate recordings. Am J Obstet Gynecol. 1998;178: 24754.

13. Patrick J, Campbell K, Carmichael L, et al. Patterns of gross fetal body movements over 24-hour observation intervals during the last 10 weeks of pregnancy. Am J Obstet Gynecol. 1982;142:363-71.

14. Patrick J, Campbell K, Carmichael L, Probert C. Influence of maternal heart rate and gross fetal body mevements on the daily pattern of fetal heart rate near term. Am J Obtet Gynecol. 1982;144:533-8.

15. Reiter RJ, Sainz RM, Antolin I, et al. Several antioxidant pathways are involved in astrocyte protection by melatonin. J Pineal Res. 2001;33:204-12. 